\title{
A FÖLDRAJZI CENTRUM ÉS PERIFÉRIA LEHETSÉGES LEHATÁROLÁSAI
}

\section{(The Pontential Definitions of the Geographical Centre and Periphery)}

\section{HORVÁTH ESZTER}

Kulcsszavak:

centrum-periféria viszonyrendszer térinformatikai alkalmazások centroid puffer-zóna Haggettféle formaindex

A centrum-periféria duál a regionális tudomány egyik legfontosabb, a földrajzi szakirodalom által gyakran használt fogalompárja. A cikkben a földrajzi periféria és a földrajzi centrum definiciójából kiindulva azok térinformatikai eszközökkel való lehatárolására teszünk kisérletet. Egyszerũ, könnyen érthetỏ és megvalósitható módszereket kerestünk, amelyeket elöször geometriai formákon vizsgáltunk, majd kilépve a földrajzi térbe a gyakorlati megvalósitás közben felmerült problémákat és megoldásaikat vázoljuk fel. A vizsgálat egy nagyobb volumenü kutatás kiindulópontja.

\section{Alapfogalmak}

Ahhoz, hogy láthassuk a centrum-periféria pontos értelmezését, legelöször a helyzetet, mint a regionális tudomány egyik központi kategóriáját kell definiálnunk. „A helyzet a helyek rendezettségi viszonya. A helyzet mindig relatív. Kedvező vagy éppen kedvezötlen helyzetről csak legalább két pont viszonylatában beszélhetünk." (Nemes Nagy 1998, 149) Leírása a távolság és az irányparaméterek megadásával lehetséges elsősorban.

A tudomány megkülönböztet értéktartalommal rendelkezö helyzeteket; ilyen például középpont, amelyhez a vizsgált rendszer többi pontja összességében a legközelebb van. De kitüntetett helyzetként értelmezhetők a súlypont, a pólus valamint a centrum és a periféria is.

A centrum-periféria relációnak három értelmezési dimenziója van, amelyek a következök:

- Helyzeti (vagy földrajzi)

- Fejlettségi (vagy gazdasági)

- Hatalmi (vagy társadalmi)

A helyzeti vagy földrajzi centrum-periféria rendszer alapja a térelemek lokalizációs megosztottsága, ahol a földrajzi távolság szerepe jelentős. Ez esetben a centrum egy kitüntetett helyzettel azonos, míg a periféria egy kủlső zónát jelöl.

A fejlettségi centrum-periféria modell alapja az értékegyenlőtlenség, a centrum térséget a fejlett területek, a perifériát az elmaradott területek alkotják. 
A belső térben kialakult térbeli relációt jeleníti meg a hatalmi vagy társadalmi centrum-periféria viszony, melynek alapja két csoport (elit és tömeg) közötti függés, egyensúlytalanság (Nemes Nagy 1998).

A geográfia az első két értelmezési szinttel foglalkozik elsősorban, de nemcsak önmagukban vizsgálja őket, hanem e két dimenzió egybeeséseit és különbözöségeit is elemzi.

Az 1. táblázat a helyzeti és fejlettségi centrum-periféria viszonyrendszer együttlétezésekor kialakuló-régiótípusokat mutatja be.

\section{TÁBLÁZAT}

A centrum-periféria pozíciók kombinációi

(Combination of the Geographic and Economic Centre-periphery Dualism)

\begin{tabular}{llll}
\hline & & \multicolumn{2}{c}{ Fejlettségi } \\
& & Centrum & Periféria \\
\hline \multirow{2}{*}{ Helyzeti } & Centrum & Központi mag & Belsö periféria \\
\cline { 2 - 2 } & Periféria & Dinamikus perem & Külső periféria \\
\hline
\end{tabular}

Forrás: Nemes Nagy 1998, 163. o.

Magyarország fỏvárosa tipikus esete a központi magnak, hazánkban a két centrumtérség szinte teljesen egybeesik, ezt a természetföldrajzi adottságok, a sugarasan kiépített közlekedési vonalak is felerősítik. Belső perifériaként értelmezhetjük az Amerikai Egyesült Államok belső területeit, amelyek bár önmagukban fejlettek, mégis gazdaságilag elmaradnak a nagy hagyományokkal rendelkező keleti és a dinamikusan fejlődő nyugati partoktól. Szlovákiában a föváros elhelyezkedése a dinamikus peremre lehet szép példa, Pozsony az egyetlen szárazföldi határ mentén fekvő európai főváros. Külső perifériaként értelmezhető Ausztria esetében a keleti Burgenland tartomány, ahol 2002-ben az egy före jutó GDP az országos átlag kétharmada, a térség a nemzeti jövedelemhez mindössze 2,3\%-kal járul hozzá.

\section{Elméleti esetek, modellek}

Az elméleti bemutatás alatt geometriai formákban gondolkodunk, eltekintve attól, hogy az adott poligon milyen méretü területegységet jelenthet a konkrét vizsgálatokban (megyét, régiót, országot), így nem kell vetületi rendszerben dolgoznunk. A cél olyan eljárások kialakítása, amelyekkel a valós térben is lehatárolhatók lesznek a területegységek. A számolásokat és az ábrázolásokat az ArcView térinformatikai szoftverrel végeztùk könnyü kezelhetősége és gyors bővíthetösége okán.

„A periféria fogalma mind a centrum, mind a határ fogalmához köthetö" (Nemes Nagy 1998, 159). E meghatározásból kiindulva két alapvető megközelítést alkalmaztam a lehatárolási módszerek kidolgozásánál és megvalósításánál hat alap poligonnal dolgoztam (1.ábra). 


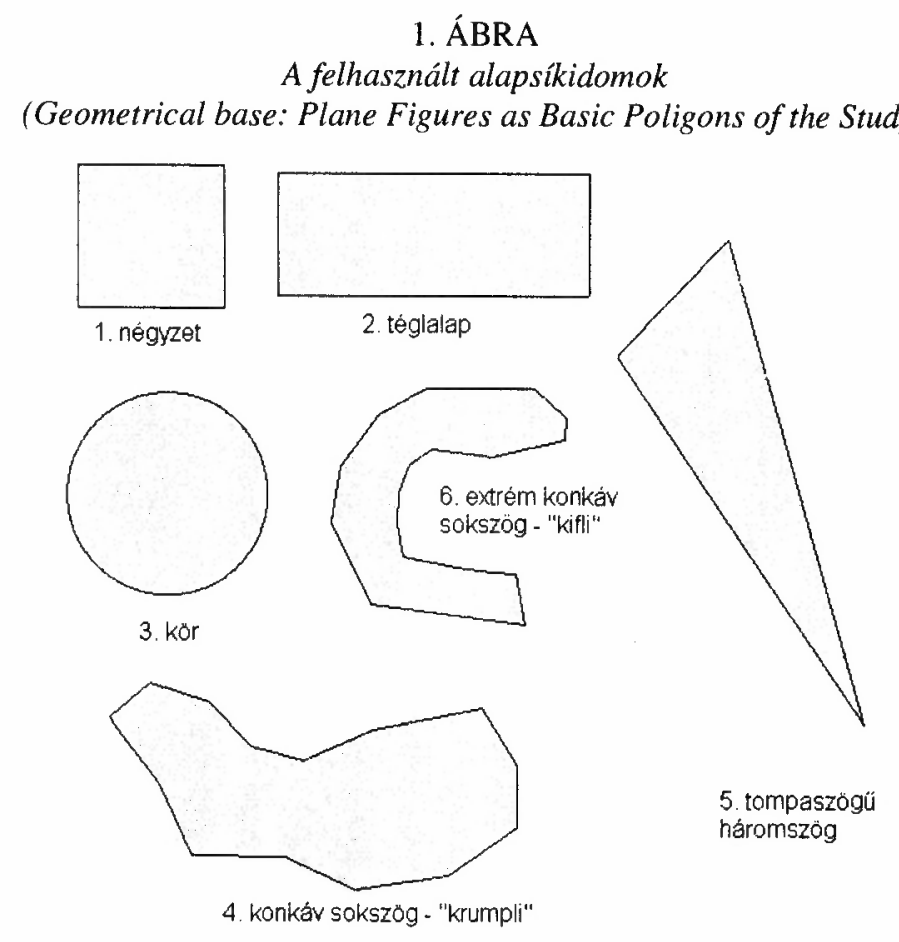

Forrás: Saját szerkesztés.

\section{A centrum felöli lehatárolás}

A centrum felöli lehatárolás abból a feltételezésből indul ki, amely szerint a periféria szorosan kapcsolódik a centrum fogalmához. Ebben az esetben célunk a centroid körüli centrumtérség kijelölése. Ezt a legegyszerübb geometriai módon az alábbiak szerint tehetjük meg.

A poligon területével megegyezö területú kör középpontját a poligon centroidjára illesztjük, amely annak felszínét részben lefedi. Azokat a területeket, melyeket e szerkesztett kör lefed, földrajzi centrumtérségeknek hívhatjuk, míg a kimaradó részek képezik a poligon perifériáját.

A lehatárolás során használt kör sugarának értéke $(\mathrm{R})$ könnyen kiszámítható a poligon területének $(\mathrm{T})$ ismeretében:

$\mathrm{Ha} \mathrm{T}=\mathrm{R}^{2} * \pi$,

akkor

$\mathrm{R}=(\mathrm{T} / \pi)^{\wedge} 0,5^{1}$ 
A felhasznált szoftver többféle ${ }^{2}$ középpont számítását is felkínálja, végül a Jeff Jennsess által megalkotott, internetről letölthető, súlypont bővítményével dolgoztam. Ennek számítási menetét a szerzỏ matematikailag pontosan definiálta.

Az alapsíkidomok esetében a középpont kijelölése és a kör meghúzása után kapott eredményt a 2. ábrán láthatjuk.

\section{2. ÁBRA}

Az alapsíkidomok súlypontjai és a ráirt kör (Centres of the Plane Figures and its Envelope Circles)

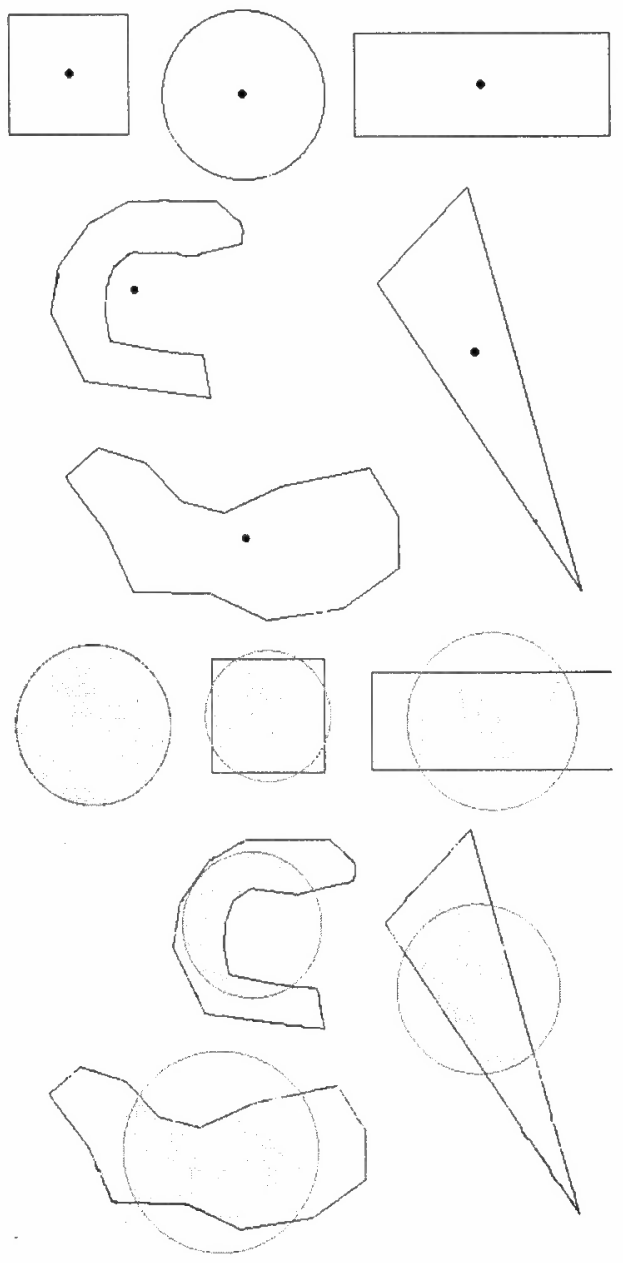

Forrás: Saját szerkesztés. 


\section{Határ felöli megközelítés}

A másik típusú lehatárolás a perifériát a határ fogalmához köti, és periférikusnak nevezi azon területeket, amelyek határtól való távolsága adott értéken belüli.

Azonban a kiválasztott távolságérték, azaz a belső puffer-zóna szélessége jelentősen függ az adott poligon nagyságától és alakjától is. E két tényezőt mindenképpen szükséges beleépíteni abba a függvénybe, amely az adott poligon puffer-zóna szélességét adja eredményül.

Az alakjellemzésre használt mutatók közül a $\mathrm{P}$. Haggett által alkalmazott $\mathrm{F}$ formaindexet használtam fel, melynek értéke

$$
\mathrm{F}=1,27 \mathrm{~T} / \mathrm{d}^{2}
$$

„Ahol $\mathrm{T}=\mathrm{az}$ alakzat területe

$\mathrm{d}=$ az alakzat két legtávolabbi pontjának távolsága

A kör F-index értéke 1 (tulajdonképpen ezért szerepel a számlálóban a konstans) a szabályos háromszögé 0,42 ; a négyzeté 0,64 ; a szabályos hatszögé 0,83 " (Nemes Nagy 1998, 202).

A poligonokhoz tehát az alak és a terület függvényében rendeltünk puffer-zóna szélességét, a következő függvény alapján:

$$
\mathrm{P}=\mathrm{F}^{*}(\mathrm{~T} / \mathrm{K})
$$

Ahol P a puffer-zóna szélessége,

F - a poligon Haggett-féle formaindexe,

$\mathrm{T}$ - a poligon területe,

$\mathrm{K}-\mathrm{a}$ kerülete (valamely teruletegység határa)

A hat alap poligon esetében a következő eredményeket kaptam (3. ábra). Érdemes megfigyelni a háromszög vékony puffer-zónáját, amelyet a kerület viszonylagos hoszszúságának és a Haggett féle formaindex alacsony értékének $(\mathrm{F}=0,17947)$ tudhatunk be.

\section{3. ÁBRA}

A poligonok határ típusú puffer-zónája

(The Natural Puffer-zones of the Poligons)
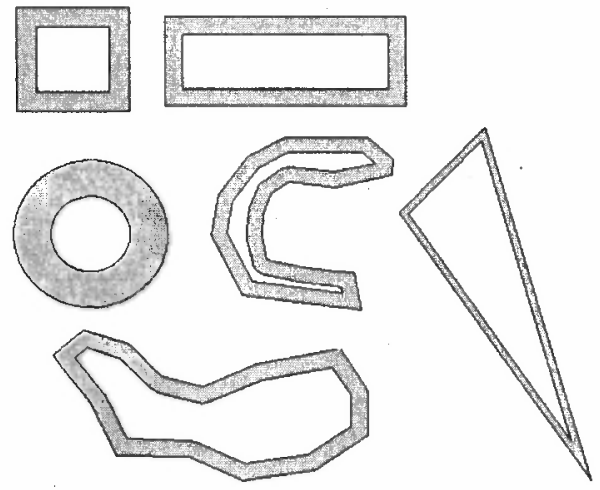

Forrás: Saját szerkesztés. 
Ugyanerre a sémára épül az a verzió is, amelyben a nevezőben található kerületértéket nem a poligon valódi kerületébỏl származtatjuk, hanem a már ismert, a poligonnal megegyező területü kör kerületét vesszük alapul. Ennek alapján a számítás a következőképp módosul:

$$
\begin{array}{ll}
\mathrm{P}^{\prime}=\mathrm{F}^{*}\left(\mathrm{~T} / \mathrm{K}^{\prime}\right) & \text { Ahol: } \\
& \mathrm{T}=\text { síkidom területe }=\mathrm{R}^{2} \pi \\
& \mathrm{K}^{\prime}=\text { síkidom területének megfelelö kör kerülete }=2 \mathrm{R} \pi \\
& \text { azaz } \\
& \mathrm{P}^{\prime}=\mathrm{F}^{*}\left(\mathrm{R}^{2} \pi / 2 \mathrm{R} \pi\right)=\mathrm{F}^{*}(\mathrm{R} / 2) .
\end{array}
$$

Ezt a típust, a nevezỏben található kerületérték miatt kerület típusú pufferzónának neveztem el. Az elmélet gyakorlati sikerességét alátámasztja, hogy a kör esetében ( $\mathrm{F}=1)$ a P' érték a sugár negyedével egyenlö.

\section{4. ÁBRA}

A poligonok kerület típusú puffer-zónája, és a két típusú zóna közötti különbség (The Circumferential Puffer-zones and the Comparison of the two Types of Puffer-zones)
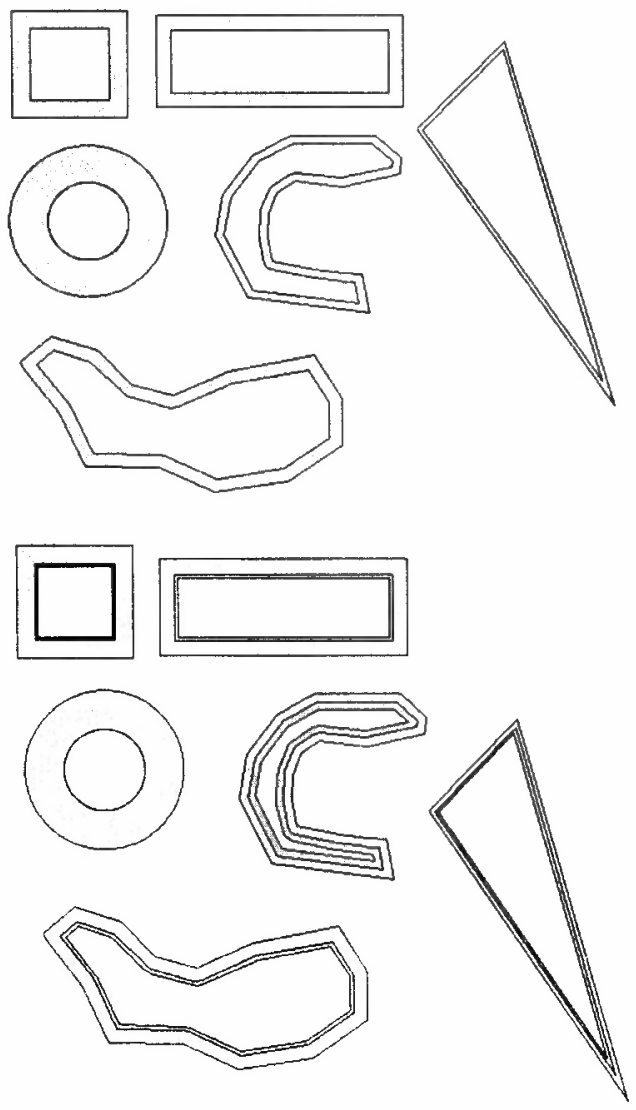

Forrás: Saját szerkesztés. 


\section{Gyakorlati alkalmazás}

Az elméleti esetek kidolgozása után a gyakorlatban próbáltam ki a fent vázolt lehatárolási típusokat; célom a világ államaiban a földrajzi perifériák és centrumok kijelölése volt. A gyakorlati alkalmazás közben több probléma és kérdés is felmerült, ezek részben a kiválasztott szint miatt, részben a módszertan miatt kerültek elö.

A számításokat, a térképi ábrázolásokat továbbra is az ArcView-val készítettem el. A felhasznált adatbázis egy 1998-as adatokra épüló mapinfo-s példafile volt, melyben az egyes államokhoz többek között a következö, fontos attribútumok voltak rendelve:

- terület (négyzetkilométerben),

- egy entitáshoz tartozó poligonok.

A kiválasztott szint első problémája a minimális területnagyság meghatározása volt, a világ közel 200 államának területi értékei nagy szórást mutattak; az alig néhány négyzetkilométeres városállamoktól kezdve a két kontinensen átnyúló Oroszországgal bezárólag.

Nemcsak az elemszám csökkentése, hanem azon földrajzi elgondolás miatt is csak a „nagyobb területü" államokat vizsgáltam, hogy a kisebb területértékek esetében a kis távolságok miatt már alig van értelme földrajzi centrum-periféria rendszerról beszélni.

Végül a területnagyságok adatsorában a további lehetséges kutatási irányokra ${ }^{3}$ való tekintettel a 30 ezer $\mathrm{km}^{2}$-es értéket választottam határértéknek.

A világszintú elemzés másik problémája a vetületi kérdés, illetve szorosan ehhez kapcsolódva az ábrázolás méretaránya volt. Az elméleti kidolgozás során, eltekintve a földrajzi vonatkozásoktól csupán geometriai alakzatokban gondolkodtam, a gyakorlati megvalósítás során azonban nem lehet a vetületi és méretarány kérdéseket figyelmen kívül hagyni.

A lehatárolások alapján mind a területnek, mind az alaknak fontos szerepe van a területegységek vizsgálatánál, így a gyakorlatban területtartásra és alaktartásra egyaránt megfelelő vetületi rendszert kellene találnunk, de e két kitétel egyidóben nem teljesülhet.

Legalkalmasabbnak talán az Universal Transverse Mercator (UTM) vetület tünik, amely egy szögtartó metszö hengervetület, ami azt jeleni, hogy a hossztorzulás csökkentése érdekében az érintő henger kis mértékben belemetsz a felhasznált forgási ellipszoidba (Detreköi-Szabó 2002) valamint minél kisebb területegységeket vizsgálunk, a torzulások mértéke annál inkább lecsökken.

Az ábrázolás kérdésénél figyelembe kellett venni az első két problémát, vagyis a minimális területnagyság elfogadása ellenére a vizsgált entitások jelentős számát, és a kisebb torzulás érdekében a minél nagyobb méretarány alkalmazását, valamint az időtakarékosság elvét is.

Ezért az országok földrajzi centrum-periféria rendszerei kontinensenként, ill. nagyrégiónként kerültek ábrázolásra, e választást segítette a már említett UTM vetület alkalmazása is. Az egyes kontinensekhez tartozó UTM szelvényeket a 2. táblázat tartalmazza. 
Horváth Eszter : A földrajzi centrum és periféria lehetséges lehatárolásai.

Tér és Társadalom 21. évf. 2007/1. 159-170. p.

\section{TÁBLÁZAT}

A kontinensek nagyrégiók esetében használt UTM szelvények

(UTM-zones of the macroregion in the study)

\begin{tabular}{lc}
\hline \multicolumn{1}{c}{ Kontinensek } & $\begin{array}{c}\text { UTM- } \\
\text { zóna }\end{array}$ \\
\hline Észak és Közép-Amerika & 11 \\
Dél-Amerika & 20 \\
Európa & 33 \\
Afrika & 33 \\
Közel-Kelet és Dél-Ázsia & 38 \\
Oroszország & 47 \\
Kelet-Ázsia & 48 \\
Ausztrália és Ú́j-Zéland & 48 \\
\hline
\end{tabular}

Forrás: Saját szerkesztés.

A gyakorlati megvalósítás eredménye Afrika példáján az 5-7. térképeken látható:

\section{5. ÁBRA}

A centrumot lehatároló körök Afrika államaiban

(Envelope circles - African countries)

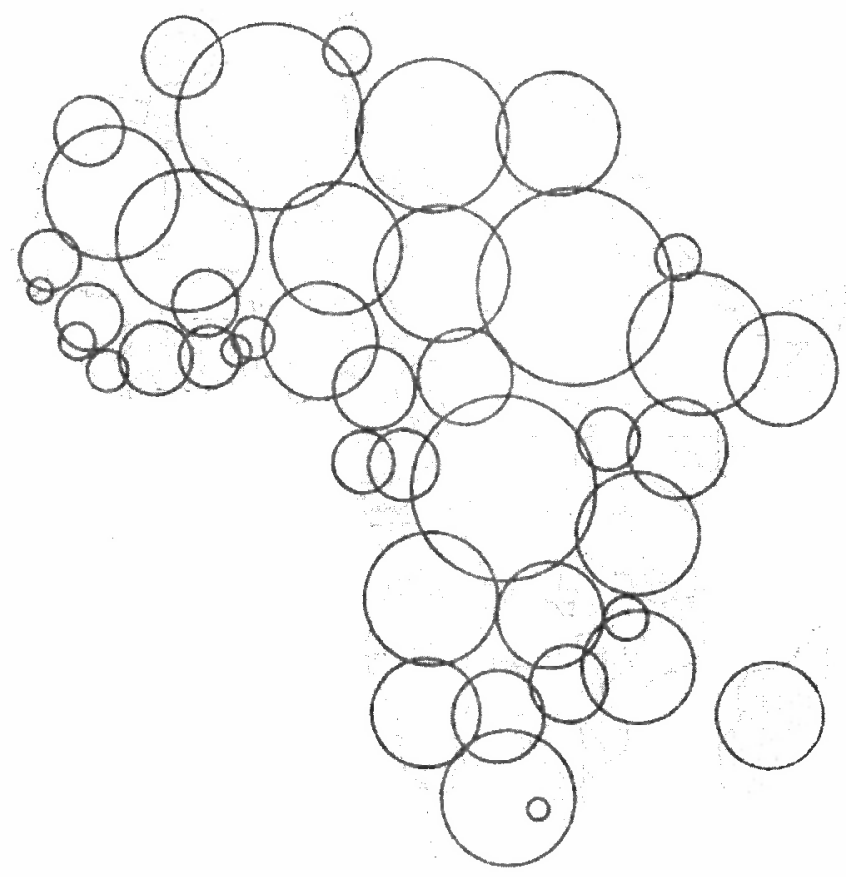

Forrás: Saját szerkesztés. 


\section{6. ÁBRA}

Határ típusú puffer-zónák Afrika államaiban

(Natural Puffer-zones - African Countries)

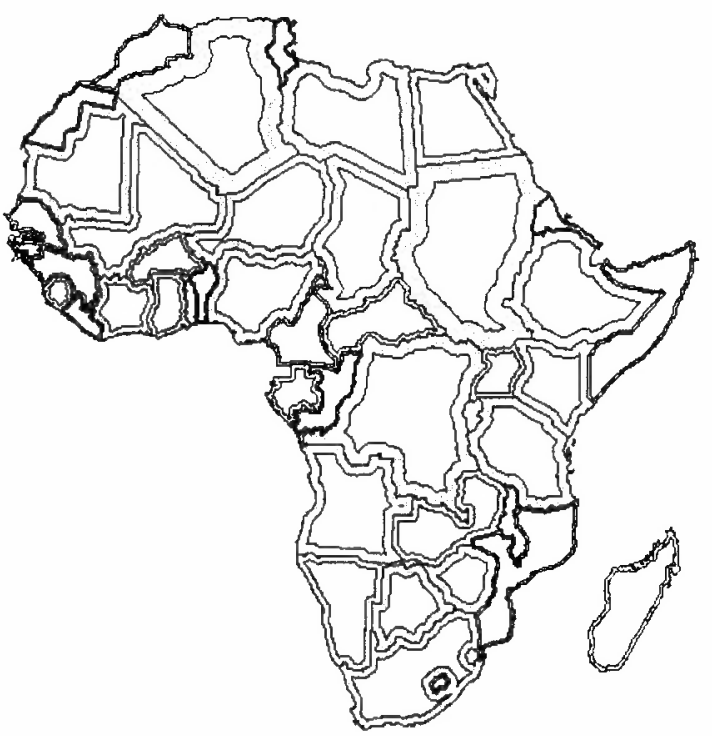

7. ÁBRA

Kerület típusú puffer-zónák Afrika államaiban (Circumferential Puffer-zones-African Countries)

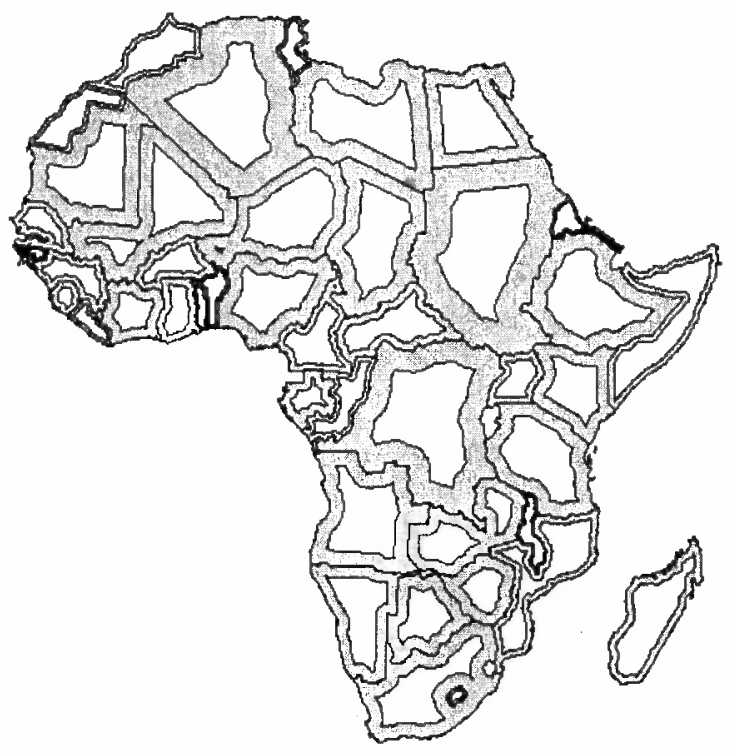

Forrás: Saját szerkesztés. 
A gyakorlati megvalósítás során felmerült módszertani problémák közül kettöt külön is érdemes kiemelni: az elsỏ a több poligonból álló entitások esete, ide tartozik a szigetországok nagy része, valamint az exklávékkal rendelkező államok is, például Oroszország (Kalinyingrád), Amerikai Egyesült Államok (Alaszka), Angola (Cabinda). Alaptérképünk adatbázisa egy entitásként értelmezte ezeket az országokat, így azokat a ,shape multipart” bővítménnyel poligonokra szedtük szét, és ezek területeit kiszámítva újbóli összevonásokat alkalmaztam a következő feltételek alapján.

Azoknál az államoknál, ahol a legnagyobb poligon területe jelentette az ország területének minimum $90 \%$-át, ott csupán ez került be a centroid számításba. Pl: Görögország (kimaradt: szigetvilág), Norvégia (kimaradt pl. Svalbard), India (kimaradt pl: Andamán-szk., Nicobar-szk.). Ugyanígy jártam el azokban az esetekben is, ahol ez az érték $80 \%$ és $90 \%$ között volt, de a következö poligonok térben jelentősen elkülönülttek az ország fő tömegétöl, és így az összevonásuk súlypontot jelentősen elmozdították volna pl. USA (Alaszka).

Azoknak az államoknak az esetében, ahol a legnagyobb területegység (sziget) aránya nem érte el az említett értékeket, és a kisebb, szintén jelentős méretú poligonok térben nem különültek el tőle, azokat összevontam, és egy egységként dolgoztam velük. Dánia esetében a három legnagyobb poligon (Jylland, Sjaelland, Fyn) összevonásával az államterület 90,5\%-át kitevő entitáshoz jutottam. További példák: Indonézia (összevonva: Szumátra, Jáva, Borneo, Celebesz, Timor, Új-Guinea) Fülöpszigetek (összevonva: Luzon, Samar, Mindanao, Cebu, Negros, Panay, Mindoro).

A megfelelő összevonás fontosságát szemlélteti az Amerikai Egyesült Államok esete, ahol két jelentősebb területet is figyelembe kell venni, az egyik a már említett Alaszka, a másik a Hawaii-szigetek. Három esetet vizsgáltunk meg ennek szemléltetésére:

Első esetben az összes poligont egy entitássá vontuk össze, a második esetben csak a törzsterületet és Alaszkát egyesítettük, végül a harmadik esetben csak a törzsterületet vizsgáltuk. A súlypontok kiszámolásánál jelentős elmozdulások figyelhetők meg. A második esetben az első súlyponthoz képest 39 km-es kelet-délkelet irányú elmozdulást regisztráltuk. A harmadik súlypont (Alaszka figyelmen kívül hagyása) további, sokkal jelentősebb 671 km-es délkeleti irányú elmozdulást mutatott.

A másik módszertani probléma, a partvonalak tagoltságának kérdése volt. Ez volt az a tényező, amely miatt felmerült a határ típusú puffer-zóna képzése mellett egy kevésbé szélsőséges eredményt adó számolási módszer alkalmazása is (így született meg a kerület-típusú puffer-zóna).

A határ típusú puffer-zóna kiszámítása során a $\mathrm{P}=\mathrm{F} *(\mathrm{~T} / \mathrm{K})$ képlet miatt azokban az államokban, amelyekben az ország tagolt határvonallal rendelkezik vagy elnyúlt a formája a puffer-zóna értéke eltorzul. Az elsö esetben a határhossz a számlálóban fordítottan arányosan módosítja a puffer-zóna szélességet, a második esetben a nagy $\mathrm{d}$ érték miatt ( $\mathrm{d}=$ az ország / alakzat két legtávolabbi pontjának távolsága) a Haggett-féle formaindex értéke mozdul lefelé, egyenes arányosságban csökkentve a puffer-zóna szélességét. Ez főként azoknál az államoknál okoz jelentős elmozdulást, amelyek mindkét említett tulajdonsággal rendelkeznek (viszonylag elnyúltak és tagolt határvonalakkal rendelkeznek). 
Példaként a Norvégia esetét mutatom be, az ország kerülete $\mathrm{K}=13256 \mathrm{~km}$, a két legtávolabbi pontjának távolsága $\mathrm{d}=1792 \mathrm{~km}$, a Haggett-féle formaindex értéke $\mathrm{F}=0,1199$. A határ típusú puffer-zóna értéke $\mathrm{P}=2,74 \mathrm{~km}$, a kerület típusú pufferzóna értéke $\mathrm{P}^{\prime}=18,65 \mathrm{~km}$. A két szélesség közötti jelentős különbséget a 8 . ábra mutatja be.

\section{8. ÁBRA}

A határ és a kerület típusú puffer-zóna Norvégia esetében

(Natural and Circumferential Puffer-zones in Norway)

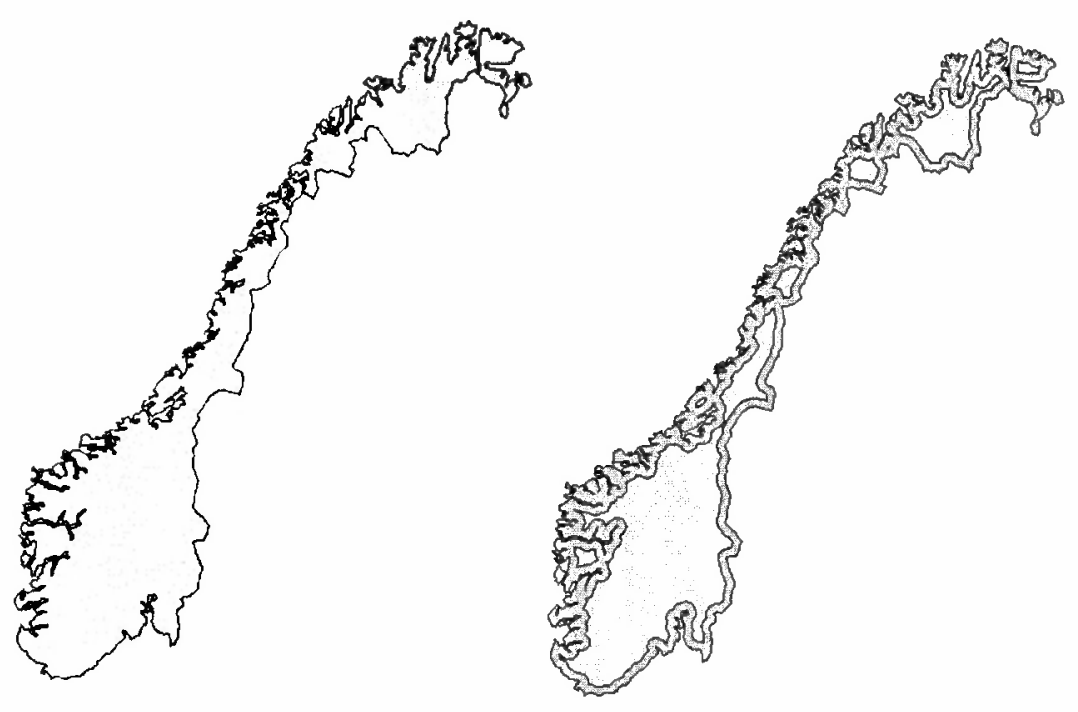

Forrás: Saját szerkesztés.

\section{A kutatás lehetséges további irányai}

A kutatás folytatásának két fő iránya kerülhet szóba. Az első a lehatárolási módszertan finomítása a félperiféria fogalmának bevonásával ${ }^{4}$, illetve a puffer-zónák kialakításánál a jellegzetes határtípusok (tengerpart, folyóvízi és szárazföldi határszakaszok) megkülönböztetésével. Ez utóbbi rávilágít a határ fogalmának több, regionális tudományból ismert értelmezésére is ${ }^{5}$.

A másik, jelentősebb vizsgálat során az államok esetében a földrajzi centrum és periféria kijelölése mellett lehatárolásra kerülnek a gazdasági centrumok és perifériák is. E vizsgálat alapját az állami szintnél alacsonyabb területegységek öt fajlagos mutatójának ${ }^{6}$ vizsgálata képezi.

Ezután elkülöníthetöek a két centrum-periféria dimenzió egybeesésének különböző esetei, amelyekről már korábban esett szó (lásd 1. táblázat). Az országok besorolása után vizsgálhatjuk az egyes típusokba sorolt államok hasonlóságait, az azonos térszerkezetet kialakító tényezőket, például a természetföldrajzi kereteket, a történelmi 
múltat, az ország alakját, kontinensen belüli elhelyezkedését stb. Meghatározhatunk hasonló térszerkezetü országokból álló, gyakran földrajzilag is összetartozó országcsoportokat, nagyrégiókat, például Afrikában a Guineai-öböl államai .

Elszakadva az államok szintjétól megfelelő vetületi rendszert választva más területi egységekre is alkalmazható a kialakított térinformatikai módszer. Ezekben az esetekben természetesen elókerülhetnek a választott szint jellegzetességeiből adódó problémák, amelyek a lehatárolások finomítását, módosítását vonják maguk után.

\section{Jegyzetek}

1 A számítások során a $\pi$ értékét 3,1415-nek vettem.

2 A pontos leírás hiánya miatt nem tudtam felhasználni az ESRI alapértelmezett centroidját. E két középpont (ESRI centroid illetve súlypont) a szabálytalan síkidomoknál jelentősen kủlönbözik.

${ }^{3} \mathrm{Ez}$ alatt az országméret alatt kevés regionális szintủ statisztikai adatot találunk. Ez Magyarország területének körülbelưl egyharmada.

${ }^{4}$ Pl.: a határ és a középpont alapú lehatárolások összevonásával.

${ }^{5}$ E határtípusok a következők: elválasztó térelem, gát (barrier), szưroỏzóna (filter), perem és ütközőzóna (frontier) és összekapcsoló elem (kontaktzóna).

${ }^{6} \mathrm{Ez}$ az öt fajlagos mutató a gazdasági fejlettség (GDP/fö), a gazdasági sürüség (GDP/ $\mathrm{km}^{2}$ ), a területegység teruiletének aránya az országon belül (\%), a területegység népessé gének aránya az országon belül (\%) és a terủletegységen elöállított GPD az országon belül $(\%)$.

7 A Guineai-öböl államainak térszerkezetét leginkább a természetföldrajzi keretek, a kontinensbe szalagtelekszerủen benyúló ország alak, a gyarmati múlt és az erre épülö gazdaság valamint kereskedelem alakította ki. E tényezók hatására a népesség és a termelés a tengerparton tömörül, megórizve a kikötỏk kiemelkedő szerepét.

\section{Irodalom}

Detrekői Á.-Szabó Gy. (2002) Térinformatika. Nemzeti Tankönyvkiadó, Budapest.

Haggett, P. (2001) Geográfia. Typotex, Budapest.

Nemes Nagy J. (1998) Tér a társadalomkutatásban. Hilscher Rezső Szociálpolitikai Egyesület, Budapest.

Nemes Nagy J. (szerk.) (2005) Regionális elemzési módszerek, Regionális Tudományi Tanulmányok 11. MTA-ELTE Regionális Tudományi Kutatócsoport, Budapest.

Raagmaa, G. (2003) Centre-periphery model explaining the regional development of the informational and transitional society. 43. Congress of the Europaen Regional Science Association.

Jeff Jennsess honlapja - www.jennessent.com

\section{THE PONTENTIAL DEFINITIONS OF THE GEOGRAPHICAL CENTRE AND PERIPHERY}

\section{ESZTER HORVÁTH}

The centre-periphery model (CPM) is one of the most important term of the regional science and an often used expression in the geographical analysis. The CPM has a lot of explanation for example geographical, economical and social CPM. The essay was looking for simple ways to separate the geographical centre and the geographical periphery with using the definitions of CPM and a tractable software (ArcView). First it put the methods to the test with two-dimensional figures, after that the study tried it in the geographical place. During analyzing the countries it found a lot of problems, comes from the methods and the examined level. This research was just an undertaking, but it can be the base of a bigger and more complex examination. 